\title{
IMPLEMENTATION AND THE IMPLICATIONS OF THE ELECTRONIC AND \\ INFORMATION TRANSACTIONS LAW AGAINST CYBER BULLYING BY \\ SUBSQUENT OF THE CONSTITUTIONAL COURT DECISION RELATED TO THE \\ FREEDOM OF SPEECH
}

\author{
Seno Wibowo Gumbira; Daryono; Ratna Nurhayati \\ Faculty of Law Social Sciences and Political Science, Universitas Terbuka \\ E-mail: seno@ecampus.ut.ac.id
}

\begin{abstract}
This article aimed to observe the criminal provisions both in the Formulation of the EIT ACT 2008 along with the verdict of the judicial review of the Constitutional Court Number 50/PUU$\mathrm{VI} / 2008$ as well as the EIT ACT 2016 especially in strictly contained in article 27 along with the norm of the criminal sanctions contained in Article 45 can still be said to be a "Rubber Articles", so it requires linguist and religious leaders in order to get a description or explanation of a remark or action in conflict with religious values and modesty as well as decency in public life. The Guarantee Of Freedom Of Speech. Then when viewed from the highest norm of the 1945 Constitution to the level of the law that is Article "Number 9 of 1998 and Article Number 39 of 1999 there is a harmony of norms and limits of freedom of speech that is the norms and values of religion, morality, public order, public interest and the integrity of the State, the concept of punishment against the actions of cyberbullying in social media in the future require an integral approach and the concept approach is criminal on parole and penal mediation with the terms limitedly and imperative.
\end{abstract}

Keywords: Cyberbullying, Electronis Information and Transactions Act, The Freedom of Speech.

\section{A. INTRODUCTION}

Globalization has penetrated almost all domains of public life in the in the field of economy, politics, science and technology,culture, education and others.although the term " Globalization " has become a vocabulary that is classic, but like it or not, people throughout the world today live in: a global, transparent, boundless, interdependent and interdependent habitat (Sulistiyono and Adji, 2009: 25). Indonesia as one of the people of the world either directly or indirectly, in the face of globalization that has penetrated almost all domains of life also have prepared all the development programs in almost all sectors of life.

302 Yustisia Vol.6 No. 2, May-August 2017 Implementation And The Implications Of The Electronic.....

(C) 2017; This is an Open Access Research distributed under the terms of the Creative Commons Attribution Licensee (https://creativecommons.org/licenses/by/4.0), which permits unrestricted use, distribution, and reproduction in any medium, provided the original work is properly cited. 
With the advances in the field of technology and also the various types of social media certainly provide a positive impact as well as the negative impact. On the positive impact and certainly very helpful in all ways especially in communication. On the negative impact, especially on social media that often happens is Cyber Bullying. At this time very much Bullying deeds that occur in social media, whether it's personal or group problems and so on. On the negative impact, especially on social media that often happens is Cyber Bullying. At this time very much Bullying deeds that occur in social media, whether it's personal or group problems and so on.

The law that one of its functions to guarantee the smooth process of national development while securing results that have been achieved should be able to protect the rights of the users of internet services at once take decisive action against the perpetrators of Cybercrime. View of the nature of Cybercrime included in the category of borderless crime, so in combating acts of Cybercrime, the necessary steps are complex, integrated and continuous of many parties, not just the job of law enforcement alone (Ariffah, Papers, 2011: 186).

In Indonesia in tackling cybercrime in the year 2008 there are provisions of legislation such as Act Number 11 of 2008 About Electronic and Information Transaction (hereinafter referred to as EIT Act 2008) and in the year 2016 and then The Laws were changed into Act Number 19 of 2016 about Electronic and Information Transaction (hereinafter referred to as the EIT Act 2016) that is certainly the substance also regulates all the actions that are considered against the law and which if done, it can be subject to Criminal sanctions. It is commonly called by the Criminalization of an action or particular deed.

Simultaneously with the emergence of various forms of social media in the lives of the global community certainly has a variety of consequences both positive and negative. In terms of the positive of course will not bring any problems, but the negatives are certainly there. The problem that's worrying is the cyberbullying is rife in various parts of the world through social media is no exception in Indonesia.

In the period of 2008 until now very many cases related to Cyber Bullying. We can take a recent case of defamation against the head of state conducted by one Indonesian citizen as well, in addition there is also an insult to one of the state officials who also made 
through social media. This is based on data and revealed by Safenet Volunteers, Daeng Ipul, Safenet documenting matters related to the case of Act EIT in Palembang and Sumatera, Makassar, to Java. According to him, there are 225 cases report related to Act EIT, but only 177 cases are verified. "From a total of 177 reports of the LAW on EIT, a total of 144 cases or of 81.5 percent ensnare men and 65 people, or 18.4 percent of women," he said in the Dialogue Dynamics of the EIT Act After Revision in Jakarta, Wednesday (28/12/2016). Social Media Facebook is the most many violations of the EIT Act. Details, 100 cases $(56,5 \%)$ cases of the EIT Act happens on Facebook, followed by Twitter, online media, short messages, YouTube, blog, email, Path, WhatsApp, online petitions, and others. In the records of Safenet, to 79.3 percent of cases reported with article 27 paragraph 3. Other article that is used is Article 28 paragraph 2 about hate speech (13\%), Article 27 paragraph 1 of about pornography (1.7 percent), and Article 29 of the threat (4\%) http://tekno.liputan6.com/read/2690352/safenet-pelanggaran-uu-ite-terbanyak-terjadi-difacebook accessed on January 1, 2017). With a presentation like this of course has the consequence of overload in prison, because the number of cases of cyberbullying in social media is increasingly growing every year. Whereas the two Articles, Article 310 paragraph (1) of the Criminal Code and Article 27 paragraph (3) of the EIT Act are rubber articles which do not mention restrictions or a more detailed ban on "defamation". This article is very open and is a soft place, the playground of legal experts (http://polhukam.kompasiana.com/hukum/2015/02/26/revisi-pasal-karet-uu-ite

703995.html?utm_source=WP\&utm_medium=box\&utm_campaign=Ktkwp accessed on January 2, 2017).

As it is known that provisions in the EIT Act 2008 and the EIT Act 2016 to address acts of cyberbullying, it turns out that the provisions of Article 27 paragraphs 1 to 3 does not change, but only there is a change in the explanation of the Article. This is as stipulated in the EIT Act 2016 which states "The provisions of Article 27 remain with the change of the explanation in paragraph (1), paragraph (3), and paragraph (4) so that the explanation of Article 27 be as set forth in the explanation article by article of the Law". If it is examined more deeply with the Decision of the Judicial Review of the Constitutional Court of The Republic of Indonesia Number 50/PUU-VI/2008 concerning the constitutionality of Article 27 paragraph 3 of EIT Act has implications for its application or not?. This is due to the 
substance between the EIT Act 2008 as amended by the EIT Act 2016 has the substance of Article 27 of the same but only changed on the explanation of the provisions of such Article.

On the other hand in addition to the problems of cyberbullying and the formulation of penal policy as that contained in the EIT Act, the above, of course, every citizen has the freedom of opinion as stipulated in the 1945 Constitution. With the guarantee of freedom of expression and freedom of opinion as stipulated in the 1945 Constitution can be used as a reason for the justification of acts of cyberbullying do not.

\section{B. PROBLEM STATEMENTS}

Based on the elaboration above, the writer wants to examine how the implementation of EIT Act 2016 in tackling acts of cyberbullying on social media often happens in the community, given there is a Decision of the Judicial Review of the Constitutional Court of the republic of Indonesia Number 50/PUU-VI/2008 concerning the constitutionality of Article 27 paragraph 3 of EIT Act so that it does have implications for its application or not? Then what is freedom of expression and freedom of speech can be the reason justification for removing a criminal on the perpetrators who commit cyberbullying? With the continued increase in cases of cyberbullying can certainly potentially the occurrence of overload in in prisons so as to provide input and find the appropriate alternative sanction formula in the prevention of future cyberbullying perpetrators.

\section{RESEARCH RESULT AND DISCUSSION}

1. Implementation And Implications Of Electronic And Information Transaction Act In Tackling Acts Of Cyberbullying On Social Media Post-Verdict Judicial Review Of Constitutional Court Of The Republic Of Indonesia Number 50/Puu-Vi/2008.

Before entering into the discussion how the implementation of Electronic and Information Transaction Act tackling cyberbullying in social media Post-Verdict Judicial Review of the Constitutional Court of the Republic of Indonesia Number 50 / PUU-VI / 2008. It is necessary to explain in advance what is meant by cyberbullying and what kind of it.

According to Smith, cyberbullying is a rough treatment performed by a person or group of people, using the electronic tools that is done repeatedly and continuously on a 
target who have difficulty defending themselves. Whereas, cyberbullying is the use of technology to intimidate, victimize, or bully an individual or group (https://mycyberbullying.wordpress.com/2014/05/25/pengertian-cyberbullying/ accessed on January 5, 2017). From this definition, it can be concluded that what is meant by cyberbullying is a crude action that can be audio and visual as well as writings that are rude or insulting by using the help of electronic devices either that can be done through social media or other electronic media.

Australian Federal Police (AFP) identifies at least seven forms of cyberbullying, which consists of (https://astriisept.wordpress.com/2014/05/22/cyberbullying/ accessed on January 20, 2017):

1) Flaming (A dispute that spreads), i.e. when a dispute that initially took place between two or more people (on a small scale) and then spread widely so that involves many people (on a large scale) so that it becomes an uproar and big problems;

2) Harrasment, i.e. a person's attempts to harass others by sending various forms of messages both writings and images that are hurting, insulting, humiliating, threatening;

3) Denigration, i.e. is someone's attempt to disseminate false news intended to damage the reputation of others;

4) Impersonation, i.e. is someone's attempt to pretend to be other people and sought a third party telling things that are confidential;

5) Outing and trickery, i.e. the efforts of someone who pretends to be other people and spread lies or these other people's secrets or a third party;

6) Exclusion, i.e. An attempt to excomunicated or exclude a person from joining a group or community for discriminatory reasons;

7) Cyber-stalking, i.e. someone attempts to stalk or follow others in cyberspace and cause harm to others.

Unlike in Indonesia, the provisions contained in Article 27 paragraphs 1 to 3 and the threat of criminal sanctions contained in Article 45 both in the EIT Act 2008 and EIT Act 2016, which if we compare in the form table that is as follows: 
Table

Difference

Article formulation of cyber bullying between EIT Act 2008 and EIT Act 2016

\begin{tabular}{|c|c|c|}
\hline & Law Number. 11 of 2008 & Law Number. 19 of 2016 \\
\hline $\begin{array}{l}\text { The } \\
\text { Formulation } \\
\text { Of The Norm }\end{array}$ & $\begin{array}{l}\text { Article } 27, \text { paragraph } 3 \\
\text { Every Person intentionally and } \\
\text { without right to distribute and / or } \\
\text { transmit and / or make accessible } \\
\text { Electronic Information and / or } \\
\text { Electronic Documents with } \\
\text { defamatory and / or defamatory } \\
\text { content }\end{array}$ & $\begin{array}{l}\text { Article 27, paragraph } 3 \\
\text { The provisions of Article } 27 \text { shall } \\
\text { remain with the amendment of the } \\
\text { clarifications of paragraphs (1), (3), } \\
\text { and (4) so that the elucidation of } \\
\text { Article } 27 \text { shall be as provided for in } \\
\text { the elucidation of Article by Article } \\
\text { of this Legislatio. } \\
\text { "Every Person knowingly and } \\
\text { without right to distribute and / or } \\
\text { transmit and / or make accessible } \\
\text { Electronic Information and / or } \\
\text { Electronic Documents with } \\
\text { defamatory and / or defamatory } \\
\text { content" }\end{array}$ \\
\hline $\begin{array}{l}\text { The } \\
\text { Explanation } \\
\text { Of The } \\
\text { Formulation } \\
\text { Of The Norm }\end{array}$ & Quite Clear & $\begin{array}{l}\text { 1) What is meant by } \\
\text { "distributing" is to transmit } \\
\text { and / or disseminate } \\
\text { Electronic Information and / } \\
\text { or Electronic Document to } \\
\text { many People or various } \\
\text { parties through Electronic } \\
\text { System } \\
\text { What is meant by "transmit" } \\
\text { is to send the Electronic } \\
\text { Information and / or } \\
\text { electronic tocument, } \\
\text { addressed to the other party } \\
\text { through the Electronic } \\
\text { System mant by "making } \\
\text { What is meant by } \\
\text { accessible" is all other } \\
\text { actions in addition to } \\
\text { distributing the } \\
\text { And transmits through } \\
\text { Electronic Systems that cause } \\
\text { Electronic Information and / } \\
\text { or Electronic documents can } \\
\text { be known to others or the } \\
\text { public }\end{array}$ \\
\hline
\end{tabular}




\begin{tabular}{|c|c|c|}
\hline & & $\begin{array}{l}\text { 2) Quite Clear } \\
\text { 3) Provisions on this } \\
\text { verse refers } \\
\text { the provisions } \\
\text { the libel and/or slander that } \\
\text { is set out in the Indonesia } \\
\text { Criminal Code. } \\
\text { The Provisions of this } \\
\text { paragraph refers to the } \\
\text { provisions of blackmail } \\
\text { and/or intimidation which is } \\
\text { set in the Indonesia Criminal } \\
\text { Code. }\end{array}$ \\
\hline $\begin{array}{l}\text { Criminal } \\
\text { Sanctions }\end{array}$ & 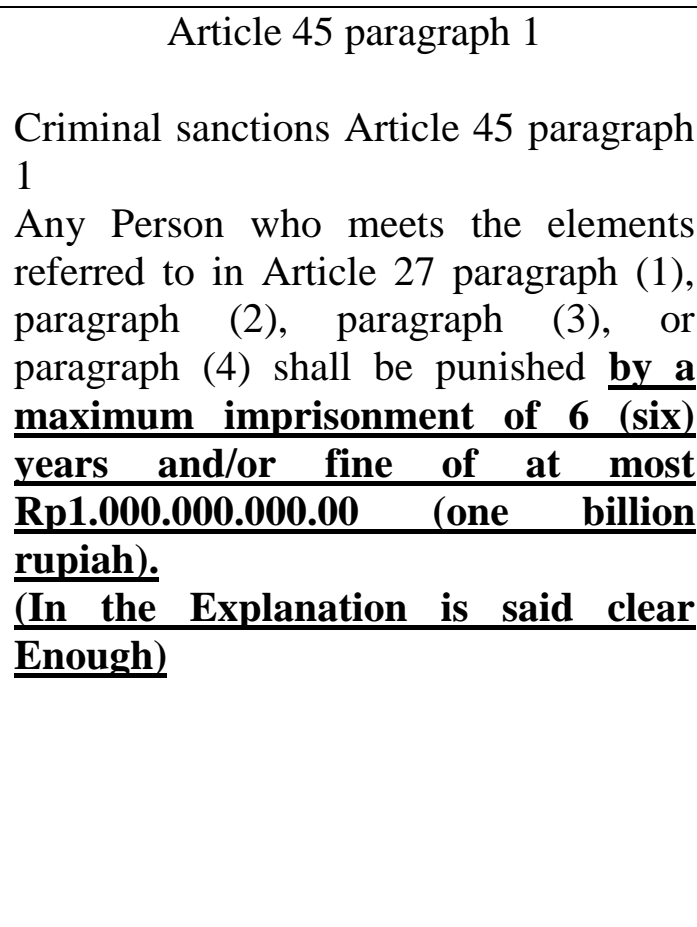 & $\begin{array}{l}\text { Article } 45 \text { paragraph } 3 \\
\text { Every person who intentionally and } \\
\text { without right to distribute and / or } \\
\text { transmitting and / or make the } \\
\text { inaccessibility of Electronic } \\
\text { Information and / or Electronic } \\
\text { Documents which have a charge of } \\
\text { insult and / or defamation as referred } \\
\text { to in Article } 27 \text { paragraph (3) shall } \\
\text { be punished with imprisonment } 4 \\
\text { (four) years and / or a maximum } \\
\text { fine of Rp750,000,000.00 (seven } \\
\text { hundred fifty million rupiah). } \\
\text { Article } 45 \text { paragraph } 5 \text { states "The } \\
\text { provisions as referred to in } \\
\text { paragraph (3) constitute offense } \\
\text { complaint" }\end{array}$ \\
\hline
\end{tabular}

Based on the table above, it can be seen there are some differences which are related to norms and sanction norm between the formulation of Article 27 paragraph 3 either at the EIT Act 2008 and the EIT Act 2016 and the threat of criminal/penal sanctions on the formulation of Article 45, paragraph 1 of the EIT Act 2008 with Article 45 of the EIT Act 2016. In the formulation of norms of Article 27 paragraph 3 of EIT Act 2008 yet there are parameters that the insult is referring to the special provisions or in the provisions of Article 310 and 311 of the criminal code of Indonesia. So it is unclear whether the qualification of the offense is normal offense or complaint offense (klacht). 
This can certainly lead to the provision of such norms to be wild or referred to as "rubber article". Coupled with the formulation of serious criminal sanctions in Article 45 paragraph 1 EIT Act 2008 with a maximum imprisonment of 6 (six) years and / or a maximum fine of Rp1.000.000.000,00 (one billion rupiah). So of course this has implications on law enforcement, namely the number of cases of cyberbullying that are processed with a qualifying offense against a regular with a sufficient amount of lots as described in the introduction section. It becomes somewhat different when the Article 27 paragraph 3 with Article 45 paragraph 1 of the EIT Act 2008 processed and terminated a judicial review by the Constitutional Court based on the decision Number 50/PUUVI/2008, which states that "The validity and interpretation of Article 27 paragraph 3 of the EIT Act 2008 can not be separated in Articles 310 and 311 of the Criminal Code as a genus of delict which requires the existence of a complaint (klacht) to be prosecuted, shall also apply to the act prohibited in Article 27 paragraph 3 of the EIT Act 2008 , So that the a quo Article should also be interpreted as a offense which requires a complaint (klacht) to be prosecuted "... so there is a Parameter with Article 27 paragraph 3 and Article 45 paragraph 1 of the EIT Act 2008.

Different is the case with the formulation of Article 27, paragraph 3, with its threat of criminal sanctions contained in Article 45, paragraph 3 of the EIT Act 2016 there are parameters as have been adopted by the decision of the judicial review of the constitutional Court Number 50/PUU-VI/2008, namely that the norm of the prohibition in the form of insults and defamation there are already explanations and parameters which refer to the Article 310 and 311 of the criminal code and further more the formulation of the criminal offense is also based with a complaint (klacht). The question is whether the complaint as Article 310 and Article 311 of the criminal code as a parameter in the provisions of Article 27 paragraph 3 of the EIT Act 2016 that also have parameters that clearly enough? It turns out that Articles 310 and 311 of the criminal code also has no clear parameters. Of all cases of libel, the article charged is Article 310 and 311 of the Criminal Code. Article 310 is classified as a rubber article because the limits are not clear. Unfortunately, it is not equipped with sufficient explanation. There is only "Quite Clear". These two chapters are very multi-interpreted. Depends on "needs" (http://www.hukumonline.com/berita/baca/hol22881/hatihati-jebakan-pasal-pencemaran 
accessed on February 20,2017). And even related to the application or implementation of the EIT Act on cyberbullying. As explained earlier that based on the decision of the judicial review of the Constitutional Court Number 50/PUU-VI/2008, which then also accommodated in the EIT Act 2016 requires a complaint according to the rules there can still be punished. But in reality without any complaints from harmed or insulted parties through social media can also be made arrest and detention first. This is seen in the case of defamation against the Chief of Police. With chronology as follows:

"Cyber Crime Team of Directorate of Special Criminal Investigation Regional Police East Java, catch the residents of Bangkalan, Madura, initials MS, a 24-year-old. The arrest was related to alleged insults made MS against the Chief of police Tito Karnavian on instagram belongs to the Police Public Relations Division Concerned do comment insults on social media instagram against officials of the state police Chief Tito Karnavian," said Head of Public Relations Division of East Java Police, Great Commissioner Frans Barung Mengera, Barung confirmed this arrest is not a matter of insulting the Police Chief Gen. Tito Karnavian. The police, he said, would crack down on anyone who insults or indulges in hate speech in social media. "Incidentally the victim is the Chief of Police," That's why he advised the public to be careful in commenting on social media. He also urged people to report to the police if they suffer similar insults. "Anyone who feels insulted in social media immediately reports to us," The police threatened MS with Article 27 paragraph (3) in conjunction with Article 45 paragraph (3) of Law Number 19 Year 2016 on EIT Act with the threat of 4 years in prison and a maximum fine of Rp 750 million. "We are waiting for the Police Public Relations Division to make a complaint," said Head of Public Relations of East Java Police (https://nasional.tempo.co/read/news/2017/05/29/078879626/hina-kapolri-dimedsos-pemuda-bangkalan-dijerat-uu-ite Downloaded on February 25, 2017).

Taking into account the case mentioned above, the existence of expansion of insulting elements that have errors in the application of Article 27 paragraph (3) ITE 2016 Act. For Article of defamation against the official or head of state the investigator 
should use Article 207 of the Criminal Code which is a normal offense (Hamzah, 2009: 179). Different on Article 319 of the Criminal Code based on the Decision of the Judicial Review of Constitutional Court Number 31/PUU-XII/2015 also is a complaint offence that where the process requires the complaint first.

So it can be stated that both the formulation of the norms and sanctions formulation norms contained in Article 27 paragraph 3 both contained in the EIT Act 2008 with the EIT Act 2016 is still no clear enough parameters in determining where the deeds classified insults and / or cyberbullying so that the potential for the occurrence of many cases of cyberbullying is carried out and the process of imprisonment or fines is quite severe, although there is a limitation of the necessity of a complaint (klacht) but can not be a parameter in defining the element of insult so that it can it is said that the provisions in the ITE Act can still be said as Rubber Article. This also remembers the customs of each region in Indonesia is different. So the qualification of this insult must be clarified to meet the lex certa element on the element of insulting someone. Does it only use restrictions on religious norms or morality norms. If any use of moral norm seems to potentially occur disparity Criminal Decision in its application. So in its application, especially in the process of verification of the trial required the expert witnesses of the language and religious leaders in determining the parameters of whether the utterance or expression of someone in social media is an act of contempt to the honor of a person as cyberbullying or not.

If you see the formulation of the Article contained in Article 310 of the criminal code that "whoever intentionally attacking the honor or good name of someone with a alleges something, that means bright so that it was known to the public, shall be punished because of libel with a maximum imprisonment of nine months or a maximum fine of four thousand five hundred rupiah". In this case according to R. Soesilo stated that in the explanation of Article 310 of the Criminal Code, explaining that, "insult" is "to attack the honor and reputation of a person". The attacker usually feels "ashamed" of "Honor" who is attacked here only about the honor of the "good name", not the "honor" in the sexual field, the honor that can be defamed by offended members of his genitals in the sphere of sexual lust (Soesilo, 1991: 225). Still in the formulation of Articles 310 and 311 in the Criminal Code, Andi Hamzah states: 
"That this offense is (delicts bestanddelen) intentionally, meaning that participants are indeed willing defame that person. If defiled his good name was indeed commit the offense charged, cannot be convicted the perpetrators of the insult. Similarly, if he committed to the public interest (algemeen belang) shall not be punished. This is the specific basis of justification in particular in the law. For the public interest it becomes his job. Judges are required to check if indeed he (the perpetrator) or force acting in the interests of self-defense. If he can not and the charges are contrary to what he knows then it will be a defamatory offense (Article 311 KUHP) which is heavily penalized, which is a maximum of four years in prison" (Hamzah, 2009: 179).

With the opinion of R. Soesilo and Andi Hamzah, then in addition to the necessary expert witnesses of the language and religious leaders in determining the parameters of whether the utterance or expression of someone in social media is an act of humiliation to the honor of a person as a cyberbullying action or not, then the additional parameters to specify a word or phrase is contained insults or categorized as an act of cyberbullying or not, then need to be dug out more clearly the element of "If defiled his good name was indeed commit the offense alleged" it is to determine whether there is an element of against the law or not.

\section{The Parameters Of The Electronic And Information Transaction In Tackling Acts Of Cyberbullying On Social Media Post-Verdict Juducial Review Of The Constitutional Court Of The Republic Of Indonesia Number 50/Puu-Vi/2008 On The Guarantee Of Freedom Of Speech}

In the provisions of The 1945 Constitution to the provisions of Article 28E paragraph 3 which states "everyone has the right to freely join the association, gathered and express opinion". Logically it can be said that The 1945 Constitution directly and expressly provides for freedom of association, freedom of assembly and freedom of expression that apply not only to every citizen of Indonesia but also citizens of foreign countries residing in Indonesia.

In addition, the provisions at the level of the Law concerning freedom of expression are also contained in Article 1 number 1 in Law Number. 9 of 1998 on 
Freedom of Expression of Public Opinion which states and explains "Freedom of expression is the right of every citizen to express thoughts verbally, in writing, and as freely and responsibly in accordance with the provisions of applicable law". In addition to Article 23 paragraph (2) of Law Number 39 of 1999 on Human Rights states that "everyone is free to have, express opinions and disseminate opinions according to their conscience, orally and / or writing through print and electronic media with regard to religious values, morals, public order, public interest and the integrity of the state ". With the existence of vertical harmonization between The 1945 Constitution and Law No. 9 of 1998 and Law Number 39 of 1999, it can be said that express opinions can be made freely both verbally and in writing but have limits and need to pay attention to the Religious norms and values, morals, order, public interest and the integrity of the state.

So when linked with criminal provisions contained in the EIT Act 2016 and Decision Judicial Review Constitutional Court mentioned above, then the use of norms of the criminal should pay attention to several aspects, whether words or expressions of legal subjects in social media violate the norms and religious values, decency, order, public interest and the integrity of the state or not? Second, the need for help from witnesses of linguists and religious leaders in their measurement. Third, it is necessary to have a complaint first from the affected subjects to be able to conduct the examination process into the realm of penal law. In addition, the position of penal provisions is also part of the limits and at the same time penal sanction which is ultimum remidium considering in the use of criminal facilities in addition to getting sanction of suffering is also paired with social stigma, in addition to remember the nature of the offense on the EIT Act 2016 is a complaint offence. This is as said by Muladi who states "the suffering of social stigma attached to" ex-con "with all its consequences related to the disruption of its civil rights accompanied by the cornering social sanction. In fact, the sufferer is not only perceived by the person but also by the family and the people who depend on it. (Muladi and RS, 2016: 60)" 


\section{The Concept Of Punisment Against The Actions Of Cyberbullying In Social Media In The Future}

Muladi stated that in the context of substantive penal law, the problems revolve around the three main problems of criminal law, namely the formulation of a prohibited act (criminalization), criminal liability (errors) and threatened sanctions, both criminal and action (Muladi, 1995: 50). So in the case of criminal defamation or cyber bullying in social media needs an intergrative penalization concept.

It is because nowadays the problem of punishment become very complex as a result of efforts to pay more attention to the factors that concern human rights, as well as make the criminal are operational and functional. This requires a multi-dimensional approach that is fundamental to the impact of criminalization, both on the impact of individual and social impacts. This kind of approach resulted in the necessity to choose the theory of integrative about the purpose of the punishment which can fulfill its function in order to overcome the damage caused by criminal acts (individual and social damage) (Muladi, 2016: 54-55). One of the serious damage from the crime of cyberbullying that victims may experience psychological pressure and can potentially suicidal. It is seen that as the data from ictwatch.com gives a picture and real that in the case of cyberbully, much more alarming. One in 5 children cyberbully victims think to commit suicide. Even 1 of the 10 victims of a cyberbully committed suicide. Within a year, there are about 4500 children who end their own lives (http://ictwatch.com/internetsehat/2012/07/11/1-dari-10-korban-cyberbully-lakukanbunuh-diri/ accessed on March $3^{\text {rd }}$ 2017). With the impact of both the perpetrators and the victims of it requires the concept of punishment that is balanced in terms of both prevention and enforcement as well as in terms of punishment for the perpetrators is balanced with the impact of the victims of cyberbullying in order to create legal certainty, justice, and expediency for social life.

When considering the formulation of the provisions of Article 45 paragraph 3 of the 2016 EIT Act stating "Any Person who knowingly and unauthorizedly distribute and / or transmit and / or make accessible Electronic Information and / or Electronic Documents with insult and / or defamatory contents as referred to in Article 27 paragraph 
(3) shall be punished by a maximum imprisonment 4 (four) years and / or a maximum fine of $\mathbf{R p 7 5 0 , 0 0 0 , 0 0 0 . 0 0}$ (seven hundred and fifty million rupiahs) ". It can be seen that the maximum punishment a special maximum imprisonment of 4 years or criminal fines of the day with a Rp750.000.000, with the alternative the imposition of a criminal with such a system with the phrase "and/or", then criminal sanctions can be in the form of the imposition of the prison accompanied by a fine only and also can be dropped on one of these penalties. So it is difficult to create a balance of sanctions and justice both for the perpetrator and the victim as well as difficult to create legal certainty, justice, and expediency for social life.

There should be a revision of the criminal sanctions more specifically based on the impact experienced by victims of cyberbullying and the circumstances of the cyberbullying perpetrator both in economic and educational terms. In terms of education, considering all users of social media is not always highly educated and intellectual and characterized according to customs with the norm of politeness and propriety. From an economic point of view, the criminal sanction is too severe between the provisions of the EIT Act 2016 maximum of seven hundred and fifty million with minor losses as stipulated in Supreme Court Regulation No. 2 of 2012 on the adjustment of the limits of minor criminal offenses and the amount of fines in the Criminal Code. This can lead to a process of criminalization the case of cyberbullying with a mild impact on the victim implicates less good in law enforcement.

The first is more likely to impose criminal penalties that can not be met by the economically disadvantaged communities. As stated by Muladi and Barda Nawawi Arief, in establishing legislative policies relating to the implementation of criminal penalties should be considered regarding:

a) A system for determining the amount or amount of criminal penalties;

b) The deadline for the payment of fines;

c) Coercive measures which are expected to guarantee the payment of fines in the event that the convicted person cannot pay within the stipulated deadline;

d) Implementation of a fine in special cases (for example a child who is immature or unemployed and still dependent on his / her parents); 
e) Guidelines or criteria to impose criminal penalties (Muladi and Arief, 2010: 181182).

In the determination of the number or amount of criminal penalty the legislative policy should consider the country's economic situation and the amount of the average income of the citizens of the country, so the implementation of criminal fines more easily implemented and become a criminal replacement of the prison, In order to avoid overcapacity / overload in prisons, in addition to avoiding criminogenic effects again between the first perpetrator to prison to be repeating his actions due to interaction with other offenders, whose impacts are not fulfilled target of the punishment is One of which is to guide the convicted person to repent and become a good and useful member of society (Poernomo, 1993: 32). It is necessary to impose a penalty by category based on the type of offense and the consequences and the maximum and minimum threats as contained in the Draft Revised Criminal Code 2006/2007 (Arief, 2010: 152-157).

Secondly, it would be more difficult to mediate between the reported party (perpetrator) and the victim so that it could potentially also happen extortion to achieve peace or difficult to reach the settlement with the concept of restorative justice.

To overcome this, it should be recalled that criminal policy is an integral part of social policy as an effort to provide social protection and as an effort to achieve social welfare (Ravena and Kristian, 2017: 87). So in addition to the need for an integral approach, the crime also requires a holistic approach with several criteria as proposed by Sudarto consisting of 4 criteria that must be considered in determining the criminalization which mainly include two things namely first Must be considered cost and benefit principle, it means that the effort to criminalize must be balanced with the results. In this case the necessity of the calculation of the cost of operating, the cost of the investigation stage to the stage of a verdict of that magnitude fixed as well as the cost of correctional institutions for perpetrators of criminal acts in the category of minor offenses whose settlement is still possible beyond the litigation of the criminal justice system, such as the schikking concept undertaken by the Attorney General in Indonesia, namely by an agreement on a fine fines in the smuggling offense between the defendant and the prosecutor, then the case is not proceeded to court (Hamzah, 2012: 10), this is done first to accelerate the settlement of criminal cases without burdening the state finances and 
achieved restorative justice between cyberbullying perpetrators and victims. Second, it should be considered whether criminalization adds the burden to the law enforcement officials so as not to cause overblasting (excess burden of the task so that the regulation is less effective (Prasetyo and Barkatullah, 2005: 42-43).

With these various considerations, then with this author provides a solution and concept for punishment pay attention and accommodate cost and benefit principle, reached restorative justice between perpetrators of cyberbullying and its victims, not to cause overblasting (extreme duty load so that regulation is less effective, i.e. with punishment alternatives to imprisonment with regard to the nature of the offense and consequences of the offense as well as the conditions of the offender. Namely as follows:

a) Criminal Parole;

b) Penal Mediation.

Criminal on parole and penal mediation as an alternative settlement and alternative punishment in addition to imprisonment and fines applied against the perpetrators of cyberbullying through social media must meet the criteria, i.e. the perpetrators still underage, not residivice in a criminal of any kind, the perpetrator is the backbone of her family, cyberbullying does not result in the victim experiencing shock of the psychic and or suicide. It is necessary to reflect the conviction that integrative and humanist who later punishment also pay attention to the factors for the welfare and humane. Consideration of a criminal on parole with the condition that limitedly certainly has some virtues as stated by Muladi, i.e., First giving an opportunity to the convicted person to improve themselves in the community, throughout the welfare of the convicted person throughout the the welfare of the convict in this case be considered as a matter of risk that may be suffered by the community if the convicted person released in the community. The second is that the criminal parole allows the convicted person to continue habits of everyday life as a human, in accordance with the values that exist in society. These habits, among others, is performing his job duties, to carry out its obligations in the family as work. The third is that the criminal conditional will prevent the occurrence of stigma caused by a criminal deprivation of liberty (jail) and the stigma often felt by his family. The advantage of the latter is that financially then criminal on 
parole who is coaching outside institution will be cheaper compared to coaching within the institution (Muladi, 2016: 152-154).

Whereas, in consideration of the concept of Penal Mediation because one part of the process to achieve restorative justice. According to Eddy O. S Hiariej restorative justice as a concept of the process which bring together the parties involved in a crime to express the suffering that they have experienced and determine what must be done to restore the state (Hiariej, 2016: 45). One form of penal mediation is the victim-offender mediation program which is the oldest restorative justice approach (Hiariej, Ibid: 47). The purpose of restorative justice from a victim-offender mediation programmes. First is to support the recovery process by giving victims an opportunity to meet with the offender to discuss with him on how to cope with the violations committed by the offender. Second, it supports the perpetrators to be directly responsible by requiring them to listen to the victim's explanation of how the impact on the victim is due to the offender's offense and to give the offender an opportunity to discuss how to overcome the violation he has committed. Third, to facilitate and encourage a process that empowers emotionally and satisfying for both parties. Fourth, the offset between the interests of the public (which became the core of the criminal justice system) and the personal interests of those most impacted by violations that have been committed. Fifth, allow the parties so they can agree on a way out of the violations that occurred (Hiariej, Ibid: 47).

With the presence of goals and the implementation of penal mediation, then it will create and eliminate the properties of discontent or resentment among the perpetrator with the victim of cyberbullying in social media. And may assume the process of penal mediation is also indirectly minimize overblasting and overcapacity in correctional institutions. So with the second concept of the criminal policy in the future reflect more of an integral part of social policy, namely as an attempt to provide protection to the community (social defence) and as an attempt to achieve the social welfare is achieved.

\section{CLOSING}

Based on the discussion then it can be drawn conclusions and suggestions as follows:

1. The formulation of criminal provisions in both the EIT Act 2008 and the decision of the judicial review of the Constitutional Court Number 50/PUU-VI/2008 and EIT Act 
2016, especially in the norm contained in Article 27 and the norm of the criminal sanctions contained in Article 45 can still be said to be a "Rubber Articles" who do not yet have clear parameters even though the limit is supposed to be a complaint from the aggrieved party or feel very bullied through social media. Though the norm contained in Article 27 in both of the EIT Act 2008 and the EIT Act 2016 refers to the Article 310 and 311 of The Criminal Code, The two chapters also still require more specific parameters for the fulfillment of lex certa element. So in each case the presence of an element of humiliation or cyberbullying requires linguist and religious leaders in order to get a description or explanation of whether a particular greeting or Such acts contradict religious values and modesty and decency in the life of the community.

2. Regarding the sub-discussion of the parameters of the Electronic and Information Transactions Act tackling acts of cyberbullying on social media Post-Verdict Judicial Review of the Constitutional Court of the republic of Indonesia Number 50/PUUVI/2008 On the Guarantee of Freedom of speech. So when viewed from the highest norm of the 1945 Constitution to the level of the law that is Law Number 9 of 1998 and Law Number 39 of 1999 there is harmony norm. That is the freedom of expressed citizens of Indonesia and Foreign while in the territory of Indonesia guaranteed expressed his opinion, but there are limitations of norms and religion values, morality, order, public interest and the integrity of the state. Meanwhile, the existence of criminal norms both in the past criminal law that is EIT Act 2008 and current EIT Act 2016 is the norm of restriction and still plays as ultimmum remidium in the imposition of criminal sanctions for people to be more careful in using social media.

3. Regarding the concept of punishment against the actions of cyberbullying in social media in the future approach requires an integral and holistic approach and pay attention to and accommodate cost and benefit principle, and achieved the restorative justice between perpetrators of cyberbullying and its victims, not to cause overblasting. As for the concept of offer is criminal on parole and penal mediation with the terms limitedly and imperatives, namely the criteria, i.e. the perpetrators still underage, not residivice in a criminal of any kind, the perpetrator is the backbone of her family, the cyberbullying does not result in the victim experiencing shock of the 
psychic and or suicide. This is so that future criminal policies more reflect an integral part of social policy that is as an effort to provide protection to society (social defenses) and as an effort to achieve social welfare. The suggestion of the formulation of the provisions of Article 27 and especially in Article 45 of the 2016 ITE Law needs to be revised by taking into account and using an integral approach and holistic approach as well as paying attention to and accommodating cost and benefit principle, achieving restorative justice between cyberbullying perpetrators and victims, not to cause overblasting.

\section{BIBLIOGRAPHY}

\section{Books and Journals:}

Adi Sulistiyono dan Rustam Adji, 2009, Hukum Ekonomi Sebagai Panglima (Economic Law as Supreme Commander). Sidoarjo, Mas Media Buana Pustaka.

Andi Hamzah. 2009. Delik-Delik Tertentu (Speciale Delicten) di Dalam KUHP (Specific offenses In The Criminal Code Indonesia) . Sinar Grafika. Jakarta. . 2012. Asas-asas Hukum Pidana Di Indonesia \& Perkembangannya (Principles of Criminal Law In Indonesia \& Its development) Medan. Soft Media.

Bambang Poernomo. 1993. Asas-Asas Hukum Pidana (Principles of Criminal Law) Jakarta. Ghalia Indonesia.

Barda Nawawi Arief. 2010. Bunga Rampai Kebijakan Hukum Pidana Perkembangan Penyusunan Konsep KUHP Baru (The Anthology Academic of Criminal Law Policy Development Drafting of New Criminal Code) Jakarta. Kencana.

Dey Ravena dan Kristian. 2017. Kebijakan Kriminal (Criminal Policy). Jakarta. Kencana.

Dista Amelia Ariffah. 2011. Kasus Cybercrime di Indonesia (Cybercrime Case In Indonesia) Makalah pada Jurnal Bisnis dan Ekonomi. ISSN: 1412-3126.

Eddy O.S Hiariej. 2016. Prinsip-Prinsip Hukum Pidana (Edisi Revisi) (Principles of Criminal Law Revised Edition) Yogyakarta. Cahaya Atma Pustaka.

Muladi. 1995. Kapita Selekta Sistem Peradilan Pidana (The Anthology Academic of Criminal Justice System) Semarang. Badan Penerbit Universitas Diponegoro. . 2016. Lembaga Pidana Bersyarat. (Criminal Parole Institutions). Bandung. Alumni 
Muladi dan Barda Nawawi Arief. 2010. Teori-Teori Dan Kebijakan Pidana (Theories and Criminal Policy) Bandung. Alumni.

Muladi dan Diah Sulistyani RS. 2016. Kompleksitas Perkembangan Tindak Pidana Dan Kebijakan Kriminal (Complexity of Criminal Progress and Criminal Policy) Bandung. Alumni.

R. Soesilo. 1991. Kitab Undang-Undang Hukum Pidana (KUHP) Serta Komentar-Komentarnya Lengkap Pasal Demi Pasal (Criminal Code And Its Complete Comments Article By Article). Politeia: Bogor

Teguh Prasetyo dan Abdul Hakim Barkatullah. 2005. Politik Hukum Pidana Kajian Kebijakan Kriminalisasi dan Dekriminalisasi (Politics of Criminal Law Policy Review of Criminalization and Decriminalization). Yogyakarta. Pustaka Pelajar.

\section{Internet:}

http://tekno.liputan6.com/read/2690352/safenet-pelanggaran-uu-ite-terbanyak-terjadi-difacebook accessed on January $1^{\text {st }}, 2017$

http://polhukam.kompasiana.com/hukum/2015/02/26/revisi-pasal-karet-uu-ite 703995.html?utm_source=WP\&utm_medium=box\&utm_campaign=Ktkwp accessed on Januar $2^{\text {nd }}, 2017$

https://mycyberbullying.wordpress.com/2014/05/25/pengertian-cyberbullying/ accessed on January 5, 2017

https://astriisept.wordpress.com/2014/05/22/cyberbullying/ accessed on January 20, 2017

http://www.hukumonline.com/berita/baca/hol22881/hatihati-jebakan-pasal-pencemaran/ accessed February 20, 2017

https://nasional.tempo.co/read/news/2017/05/29/078879626/hina-kapolri-di-medsos-pemudabangkalan-dijerat-uu-ite/ downloaded on 25

http://ictwatch.com/internetsehat/2012/07/11/1-dari-10-korban-cyberbully-lakukan-bunuh-diri/ accessed on March $3^{\text {rd }}, 2017$

\section{Regulations:}

The 1945 Constitution

The Criminal Code Indonesia

Draft Revised Criminal Code in Indonesia 2006/2007 
Law Number 11 of 2008 On The Information And Electronic Transactions

Law Number 19 of 2016 On The Amendment of Law Number. 11 of 2008 on the Electronic and Information Transaction

Law Number 9 of 1998 On The Independence Provides a Public Opinion

Law Number 39 of 1999 On The Human Rights 